\title{
СЕЛЬСКОЕ ХОЗЯЙСТВО
}

УДК 346.32

\section{ОСОБЕННОСТИ ИНВЕСТИРОВАНИЯ В ЦИФРОВОЕ СЕЛЬСКОЕ ХОЗЯЙСТВО}

\author{
Шпинев Юрий Сергеевич, \\ кандидат юридических наук, \\ e-mail: shpinev.iurii.sergeevich@mail.ru, \\ Институт государства и права РАН РФ, \\ Москва, Российская Федерачия
}

\begin{abstract}
Аннотация: В работе рассматриваются особенности инвестирования с сельское хозяйство в период его циифровизации. Проанализированы инвестиционные риски, присущие сельскому хозяйству как специфической отрасли. Выделены основные направления развития изифрового сельского хозяйства. В заключении сделан вывод о необходимости внесения изменений в правовое регулирование инвестиций в агропромышленный холдинг с иелью привлечения дополнительных инвестиций от частного сектора, необходимых для скорейшего перехода $к$ цчифровому сельскому хозяйству.
\end{abstract}

Ключевые слова: инвестиции, инвестищии в сельское хозяйство, циирровое сельское хозяйство, инвестиционные риски.

\section{FEATURES OF INVESTMENT IN DIGITAL AGRICULTURE}

\author{
Shpinev Iurii Sergeevich, \\ PhD in Law, \\ e-mail: shpinev.iurii.sergeevich@mail.ru, \\ Institute of State and Law of the Russian Academy of Sciences, \\ Moscow, Russian Federation
}

\begin{abstract}
: this paper discusses the features of investing in agriculture during its digitalization. Investment risks inherent in agriculture as a specific industry are analyzed. The main directions of digital agriculture development are highlighted. In conclusion, it is concluded that it is necessary to make changes to the legal regulation of investments in agro-industrial holding in order to attract additional investment from the private sector, which is necessary for the rapid transition to digital agriculture.
\end{abstract}

Keywords: investment, investment in agriculture, digital agriculture, investment risks.

\section{САНАРИПТИК АЙЫЛ ЧАРБАСЫН ИНВЕСТИЦИЯЛОО ӨЗГӨЧӨЛУКТӨРУ}

Шиинев Юрий Сергеевич, юридикальк илимдердин кандидаты, e-mail: shpinev.iurii.sergeevich@mail.ru, 
Аннотация: Макалада санариптештирҮҮ мезгилинде айьл-чарба тармактарында инвестищия салуунун өзгөчөлүктөрүн карайт. Айыл чарбасына мүнөздүү өзгөчөлҮY тармак катары тийиштүҮ инвестициялык тобокелдиктер талданды. Санариптик айыл чарбасын өнүктүрүүнүн негизги багыттары аныкталды. Корутундуда ошондой эле санариптик айыл чарбага тез арада өтҮY Үчүн жеке сектордон кошумча инвестищияларды тартуу максатында агроөнөр жай холдингие инвестицияларды укуктук жөнгө салууга өзгөртүүлөрдү киргизүү зарылдыгы жөнүндө тыянак жасалды.

Негизги сөздөр: инвестиция, айыл чарбасына инвестиция, санариптик айыл чарбасына инвестиция, инвестицияльк тобокелчиликтер.

Agriculture is increasingly acquiring the properties of a knowledge-intensive branch of the national economy. Currently, the use of the necessary information received on time and processed efficiently using the latest technologies can significantly increase labor productivity, which in turn reduces costs and makes the agro-industrial complex an interesting object for investment.

Agriculture, along with the mining and construction industries, is one of the most sensitive sectors of the economy to economic and political crises. The volume of investment in these industries decreases most actively during such crises (1, 356).

In addition, the agricultural sector is considered to be more risky in terms of investment compared to other sectors of the economy due to the special conditions of economic activity. These specific conditions consist primarily in the fact that many economic factors here depend on natural phenomena, which people do not always have the opportunity to influence $(2,174)$. Such investment risks that distinguish agriculture from other branches of law include the following:

- the probability of diseases of crops and animals despite all precautionary measures (swine flu, avian flu);

- the risk of reducing the planned harvest due to natural phenomena that cannot be predicted in the long term (drought, flood, hurricane, hail, etc.);

- the possibility of recognizing any animals as vectors of human diseases and, as a result, the total destruction of their population in a certain territory (swine flu, destruction of Minks as carriers of COVID 19);

- the emergence of a situation in which a large crop of an agricultural product leads to an oversupply of this product on the market and, as a result, to a decrease in its price, and companies engaged in its cultivation to a loss instead of profit.

These risks have an additional negative impact on the investment attractiveness of the industry. Given this, almost no country can successfully develop agriculture without the active participation of the state and public investment. At the same time, scientists have found that the effectiveness of such 
assistance increases dramatically with increasing investment in fixed assets of agricultural companies $(3,43)$.

It should be noted that these risks are more or less inherent in agricultural enterprises of all economies, both developed and developing $(4,756)$.

As for the Russian agro-industrial sector, taking into account the economic and political realities, the list of negative factors that negatively affect the investment attractiveness of the industry can be expanded by the following potential threats:

- credit risks, since the vast majority of agricultural enterprises have, thanks to the financial support of regional and Federal authorities, a large number of current loans, as a result of which the over-crediting of many farms and agricultural holdings exceeds the real possibilities;

- technical risks that consist in the deterioration of the material and technical base of agricultural enterprises, and first of all (more than $60 \%$ ) of agricultural machinery (5);

- sanctions related to both the possibility of limiting the supply of innovative equipment or fertilizers, and the ban on the sale of finished products on traditional markets.

Thus, we can conclude that one of the most vital branches of the national economy for any state has a large set of negative factors that negatively affect its investment attractiveness, which makes it inevitable that the state will actively participate in both financing and overall coordination of the agro-industrial sector $(6,165)$

In most developed countries, investment in agriculture is encouraged and supported by the state. The main directions of investment policy in this sector of the economy are aimed at increasing production, actively using the latest technical, technological and managerial achievements. In recent years, the relatively expensive industrial economy in these countries has been replaced by a knowledge economy. Major investors and agricultural giants prefer to invest in research and further industrial development in this sector of the economy. It should be noted that in advanced agricultural countries, not only the state invests in the agricultural sector, but also private companies and corporations. Such investments bring good dividends. As a result of competent investment activity, labor productivity in agriculture increases five times. Meanwhile, research spending is not the largest part of investment in agriculture. Three times more is spent on the development and implementation of technologies than on scientific research itself $(7,147)$.

Taking into account the need for large investments in the agro-industrial sector of the economy in developed countries, there are whole sets of measures aimed at encouraging and supporting agricultural investors. 
For example, the United States has developed and successfully operates a national innovation system, through which the Department of agriculture helps agricultural companies develop technological conditions for obtaining better indicators, which ultimately contributes to the growth of investment in agroindustrial technologies.

In order to support investment in agriculture, the Ministry makes extensive use of such mechanisms as grants, financial support for universities and research laboratories specializing in agriculture.

Universities have special innovation clusters that are funded by the state.

All these and many other measures of state support have a positive impact on the agro-industrial sector and increase confidence in the current government, since the formation of innovations in agriculture in the United States is closely linked to ensuring food security (8).

The EU attaches great importance to the investment policy in the agroindustrial sector, which is designed to help and develop small scientific companies, innovation centers and technology parks.

South-East Asian countries do not lag behind in the development of innovative agriculture, where investments are directed to the creation and development of innovation and incubation centers $(9,759)$.

Investment support for the agro-industrial complex of developed agricultural countries has common properties:

- the state and big business act as a guarantor and organizer of inversion support for the agricultural sector, while the main participants in the development of the industry are small and medium-sized businesses;

- there is a well-established system of balanced and mutually beneficial relations between business and the state in matters of investment;

- there are various ways of interaction between the state and commercial enterprises, as well as individuals;

- the distribution of income takes into account intellectual property rights;

- constantly assesses the effectiveness of scientific and industrial interaction between the state and industry enterprises at various state levels;

- transparent and non-changing fiscal policy that encourages agricultural development;

- tax incentives for investment support of innovative development;

- special technical centers for the transfer of the latest technologies and innovative services have been approved and are actively functioning;

- the state does not participate in the receipt and distribution of income from scientific research, but controls the financial results of contract activities. 
Among the main areas of state support for investment in agriculture in developed foreign countries, the following can be distinguished:

- creation and active functioning of a unified national system for innovative development of the agro-industrial complex (making changes to the organization of scientific research in the public sector, combining higher educational and scientific institutions, developing and supporting innovative companies of small and medium-sized businesses, as well as export production);

- creating the most favorable system for the development of the agroindustrial complex using the latest achievements of science and technology (changing the functioning of public administration and planning to address issues of investment development, increasing funding for scientific research, encouraging basic scientific research);

- interaction between science and the agro-industrial code (additional funding for the integration of science and agricultural production, encouraging private investment in national innovative developments, creating conditions for attracting foreign capital to research, actively stimulating the production of innovative products, attracting regional Finance for research).

Thus, we can conclude that the main activities of States related to increasing the investment attractiveness of agriculture are aimed at obtaining new scientific knowledge, introducing innovative technologies and developing the digital economy.

The digital economy primarily refers to economic activities based primarily on digital technologies and related to e-business and e-Commerce, as well as electronic goods and services. Its development is closely linked to a breakthrough in the scientific, technological, and socio-economic development of Russia.

To implement the digital economy in agriculture, the Ministry of agriculture of the Russian Federation adopted the departmental project «Digital agriculture» in $2020[10]$.

According to this document, digital agriculture refers to agriculture based on innovative ways of producing agricultural products using digital technologies, including robotics, e-Commerce, analysis of large databases, the Internet of things, etc., which contribute to increasing labor productivity and reducing costs.

Agriculture includes several areas, the main of which are crop production and animal husbandry $(11,65)$.

Some authors also highlight digital agriculture, including:

- setting the boundaries of agricultural land using satellite navigation;

- electronic calculation and automatic soil fertilization;

- creation of digital maps;

- yield planning using artificial intelligence; 
- monitoring and protection of crops using unmanned aerial vehicles;

- remote sensing, etc. $(12,5)$.

Creating digital agriculture includes the following activities:

- data collection, processing, storage and use;

- modeling, forecasting and planning of future crops;

- multi-functional fitness assessment;

- distribution of production capacity and resources;

- design of landscape systems, etc. $(13,523)$.

As positive aspects of the use of artificial intelligence in enterprises of the digital agro-industrial complex, scientists highlight:

- an increase in industrial indicators, as well as a reduction in costs;

- optimization of business processes, increasing the speed of making and efficiency of management decisions;

- reduction of the same type of manual operations, resulting in the possibility of using the creative potential of employees;

- improvement of technologies in agriculture and agro-industrial complex using neural networks and machine learning;

- creation of new high-tech jobs in the field of maintenance of the latest innovative systems;

- technological and economic breakthroughs when using the full potential of digital agriculture $(14,570)$.

Certain factors may hinder the active implementation of some components of digital agriculture in the agro-industrial complex. These factors include:

- lack of Finance in agricultural enterprises;

- lack of trained personnel;

- the presence of outdated infrastructure that is unable to ensure the proper functioning of innovative technologies;

- some agricultural workers do not perceive innovative technologies;

- high cost of innovative technologies using artificial intelligence;

- the complexity of determining the economic benefits of using certain components of digital agriculture;

- Russia's scientific and technological lag behind the leading countries;

- lack of proper legal regulation of relations arising in the functioning of digital agriculture.

In order to eliminate the lack of legal regulation, it is proposed

- introduce the definition of digitalization as one of the main directions of the state's agricultural policy at the present stage in strategic laws and other regulations in the field of agro-industrial complex development; 
- bring legislative acts in the field of agricultural policy in line with the documents of strategic planning in the field of digitalization of the economy;

- Supplement the Federal law «On the development of agriculture» with regulations on state support for domestic agricultural producers investing in digital technologies;

- make changes to civil legislation in connection with the introduction of the concepts of «digital economy» and «digital agriculture»;

- establish new environmental and technological standards and standards (15, 20).

According to scientists, the introduction of e-agriculture will help agricultural enterprises successfully solve many problems, including:

- increase production by optimizing operations including proper planting, watering, pesticide treatment, and harvesting;

- rational water use through accurate weather forecasts and the use of soil moisture sensors;

- getting all the necessary information in real time, which makes it possible to speed up the analysis and decision-making time as much as possible;

- reduced operating costs due to automation and robotization of industrial processes, which in turn reduces the likelihood of human error;

- improvement of product quality due to the implementation of product quality analysis;

- improvement of animal husbandry through the use of modern electronic sensors that can track the condition of animals, as well as their location;

- remote monitoring of farmland, as well as monitoring the condition of equipment with testing and fault prediction $(16,48)$.

Ultimately, the above-mentioned improvements related to agriculture can lead to an increase in the investment attractiveness of the agro-industrial complex.

The General properties of investment security in Russia that significantly affect the investment process include the following:

- the leading role in investment policy belongs to the state;

- investment passivity on the part of private businesses;

- partnership relations between the private business of the agro-industrial complex and the state are at the stage of formation;

-when using scientific and technical developments, agricultural enterprises make compensation payments in favor of the state;

- the interaction between all participants in investment relations on income distribution is not fully regulated;

- lack of understanding of the status, role and functions of scientific and technical structures operating on the basis of state funding; 
- there is no transparent mechanism for tax incentives for investment in small and medium-sized businesses;

- legislation in the field of taxation and investment security is constantly changing, which leads to inconsistency of legislation in the field of investment.

Thus, we can state that agriculture is a very interesting area of investment from the point of view of studying. On the one hand, this industry is the most important, strategic sector of the economy for any state, which in principle should guarantee investors minimal risks. On the other hand, the specifics of the industry determine additional investment risks.

Given its strategic importance, agriculture is regulated by public law on many issues, although most legal relations are in the sphere of private law.

The beginning digitalization of the agro-industrial complex can level out many investment risks and make the industry more attractive to potential investors. However, for the full digitalization of agriculture, investments are needed, which are quite problematic to attract for the reasons outlined above.

Domestic agriculture, in addition to General difficulties, faces insufficiently developed legal regulation of investment processes in the agro-industrial complex. Until the main gaps in legal regulation are resolved (transparency of investment and stability of tax legislation, real benefits and compensation for investors and enterprises investing directly in e-agriculture, strict regulatory consolidation of the rules for using the latest scientific achievements and innovative technologies in agriculture, etc.), it will be quite problematic to attract private investors to this sector of the economy, and the difficult economic situation may prevent full digitalization only at the expense of public investment.

\section{List of references}

1. Ankudinov A. B., Dashkin R. M., Dashkin E. M., Khasanov T. I. Determinants of investment behavior of emerging market companies // Economic attitude. 2020. Vol. 10. №. 2. Pp. 341-362.

2. Fayzrakhmanov D. I., Khairullina A.D., Khazeev L. F. Investment risks in agriculture and integration of their management mechanism into the overall management system of the enterprise // Bulletin of Kazan state agricultural UNIVERSITY. 2019. № 3 (54). Pp. 173-177.

3. DOI 10.12737 / article_5db99732317e48. 92407015.

4. Valerianov A. A., Kornilova D. M., Levanova T. A. Influence of state support on investments in agriculture of the Chuvash Republic // Innovative development of the economy. 2018. № 1 (43). Pp. 35-43.

5. Rusakova E. P., Frolova E. E., Zankovsky S. S., Kupchina E. Problems of implementing leadership in resolving disputes in the BRICS countries (on the example of the RUSSIAN FEDERATION, CHINA, INDIA) in the book: the 6th International Conference on education, social and humanitarian Sciences. 2019. Pp. 754-759.

6. «Rosagroleasing» asks for money to replenish the authorized capital. [Electronic resource]. - URL: https://iz.ru/news/658424 (accessed 11.10.2020). 
7. Cherkesova L. I. Historical and legal review of the formation of the Ministry of justice of the Russian Empire // In the collection: Problems of national history. Moscow. 1999. Pp. 163-174.

8. Battakov P. P. Court of the Russian Federation for intellectual property rights // Eurasian legal journal. 2013. № 12 (67). Pp. 147-148.

9. Rykhtik M. I., Korsunskaya E. V. national innovation system of the USA: history of formation, political practice, development strategy // International relations. Political science. Regional studies Bulletin of the Lobachevsky University of Nizhny Novgorod. 2012. № 6 (1). pp. 263-268.

10. Babaeva Z. Sh. Investments in agriculture: experience of foreign countries // Current issues of the modern economy. 2020. № 5. Pp. 758-762.

11. Ministry of agriculture. Departmental project «Digital agriculture». [Electronic resource]. - Access mode-URL: https://mcx.gov.ru/upload/iblock/900/900863fae06c026826a9ee43e124d058.pdf (accessed: 11.10.2020).

12. Lisikova M. S. Environmental law. Educational and methodical complex / Moscow. 2007. $76 \mathrm{p}$.

13. Kiryushin V. I., Ivanov A. L., Kozubenko I. S., Savin I. Yu. Digital agriculture / / Bulletin of the Russian agricultural science. 2018. № 5. P. 5.

14. Ivanov A. L. Scientific and technological development of land use using digital technologies in agriculture / / Bulletin of the Russian Academy of Sciences. 2019. № 5. P. 523. DOI: 10.31857/S0869-5873895522-524.

15. Skvortsov E. A. Prospects of application of artificial intelligence technologies in agriculture of the region // Regional economy. - 2020. - Vol. 16, issue 2. - Pp. 563-576. DOI http://doi.org/10.17059/2020-2-17.

16. Voronina N. P. Digital agriculture of Russia: Directions for improving legal regulation / / Ius Publicum et Privatum. 2020. № 4 (9). Pp. 18-21.

17. Eldieva T. M. Direction of using smart innovations in agriculture // international agricultural journal. 2018. № 6 (366). Pp. 46-49. DOI: 10.24411/2587-6740-2018-16094. 